\title{
EFFECT OF PACKING MATERIAL AND ITS GEOMETRY ON THE PERFORMANCE OF PACKED BED COLLECTOR
}

\author{
Sandeep Kumar ${ }^{1}$, Lokesh Varshney ${ }^{2}$ \\ ${ }^{1}$ Teaching Personnel, Department of Mechanical Engineering, College of Technology, G.B. Pant University of \\ Agriculture \& Technology, Pantnagar 263145, Uttarakhand, India \\ ${ }^{2}$ Professor, Department of Mechanical Engineering, College of Technology, G.B. Pant University of Agriculture \& \\ Technology, Pantnagar 263145, Uttarakhand, India
}

\begin{abstract}
It has been well established that packed bed solar collectors perform better as compared to conventional collectors. Results of performance studies on packed bed solar collector are available in literature in which different operating conditions have been considered which make it difficult to compare their performance accurately. Considering this comparative study of performance of solar collector with different packing elements has been made in the present work. Experimental investigations on solar collector packed with iron chips, wire mesh, gravels and glass balls for the same set of operating parameter have been done on a single setup to study the effect of packing material and its geometry on the thermal efficiency of packed bed collector. It is observed that iron chips packed collector is identified as the best packing materials out of the materials selected for study leading to thermal efficiency of $76.21 \%$ for the mass flow rate of $0.035 \mathrm{~kg} / \mathrm{s}$ and porosity of 0.945 , which is $69.58 \%$ higher as compared to smooth collector. Thermal efficiency of wire mesh packed collector for similar operating conditions is found to be $74.26 \%$ which is $65.24 \%$ higher than smooth collector. In low porosity range gravel packed collector is found to perform better as compared to glass ball packing. Effect of mass flow rate on the effective efficiency has also been conducted for various packing elements used in the present study. Based on the experimental results, plots have been drawn for efficiency against temperature rise parameters for different packing elements which can be used by the designer for choosing the correct value of mass flow rate for the specific temperature rise application.
\end{abstract}

Key Words: Solar Collector, Iron Chips, Wire Mesh, Gravels, Glass Balls, Packed Bed.

\section{INTRODUCTION}

Solar energy is one of the cheapest and environment friendly renewable energy source. It can be used in different applications by making different arrangement of collection, storage and transmission. Out of many applications one is solar air heater which intercepts the solar radiation to heat the in air and delivers the air for use in various applications like space heating, drying agricultural crop etc. But the major drawback of conventional solar air heater is its poor thermal performance. In order to improve the thermal performance of conventional solar air heater concept of porous packed bed collector is introduced by previous investigators. By packing the porous media like wire mesh, glass wool, iron turnings, pebbles etc. inside the duct of collector the heat transfer area to volume ratio increases which enhances the heat transfer rate. By doing so, instead of absorber plate porous packing material also act as an absorber. Solar radiations are deeply absorbed by the packing elements which in turn reduce the top losses and hence increase the outlet temperature of the collector. But while enhancing the thermal performance of conventional collector by using the porous packing element, there is also a simultaneous abrupt increase in pressure drop across the duct. So there is also need of optimization of less pressure drop which has a direct impact on the running cost of the system.
Use of porous packing inside the flow passage of the duct such as wire screens inside the tubes of heat exchanger [14], slit and expanded aluminium foil matrices [5], iron savings and wires[25], iron chips aluminium chips and pebbles [16], wire mesh screen $[20,1,30,28,21]$, rachig rings[17], copper screen mesh [29], gravels [27], heater with fins attached and steel wires[18], steel wool and glass wool [13] are various methods used by different investigators to study the thermal performance of packed bed collector. It has been observed that the work carried out by different investigators using various packing materials under different environment has been reported in the literature with different operating parameters. In order to have a better comparison of performance with different packing's it was desired to conduct experiments on a single setup and under similar operating conditions. This will help in predicting the performance of a collector and compare them more accurately. With this objective in mind the present work is undertaken to investigate the thermal performance of collector using different porous packing elements (like iron chips, wire mesh, gravels, and glass ball) for same operating conditions on a single setup. Study is done to check the effect of geometrical parameters on the performance of the collector for different packing materials. Study of various operating parameter on the performance of collector is also made considering various packing elements. The parameters of packing elements considered in the present work involve 
porosity in the range from (0.945-0.986) for iron chips and wire mesh. Porosity for gravels and glass balls in the range of (0.4-0.45) for mass flow rate ranging from 0.01 to 0.035 $\mathrm{kg} / \mathrm{s}$. Experimental tests were done under identical simulated conditions for a packed bed collector and also for smooth solar collector, so as to compare the results of packed bed collector with conventional smooth collector.

\section{EXPERIMENTAL SETUP}

Fig.1 shows the layout of an experimental setup that has been designed and fabricated in accordance with [3] to collect data for evaluating the value of heat transfer and pressure drop.

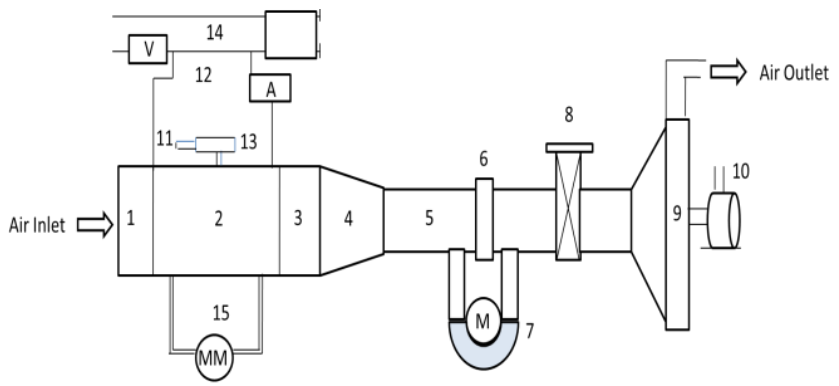

Fig.1: Details of the experimental setup

\begin{tabular}{|l|l|l|}
\hline $\begin{array}{l}\text { 1.Flow } \\
\text { Straightener }\end{array}$ & 2.Test Section & 3.Exit Section \\
\hline $\begin{array}{l}\text { 4.Mixing } \\
\text { Plenum }\end{array}$ & 5.G.I.Pipe & 6.Orifice Meter \\
\hline $\begin{array}{l}\text { 7.U-tube } \\
\text { Manometer }\end{array}$ & 8.Gate Valve & $\begin{array}{l}\text { 9.Centrifugal } \\
\text { Blower }\end{array}$ \\
\hline $\begin{array}{l}\text { 10.Electric } \\
\text { Motor }\end{array}$ & 11.Selector Switch & $\begin{array}{l}\text { 12.Voltage } \\
\text { Variac }\end{array}$ \\
\hline $\begin{array}{l}\text { 13.Temperature } \\
\text { Indicator }\end{array}$ & $\begin{array}{l}\text { 14.Voltmeter and } \\
\text { Ammeter }\end{array}$ & $\begin{array}{l}\text { 15.Digital } \\
\text { Manometer }\end{array}$ \\
\hline
\end{tabular}

For stabilizing the flow, a flow straightener has been provided towards entry side of air. As per the recommendations in [4] the length of flow straightener section downstream of the test section should have a minimum value of $5\left(\mathrm{~A}_{\mathrm{f}}\right)^{1 / 2}$, so the length of the entry section taken as $650 \mathrm{~mm}$. The size of entire duct is $2150 \mathrm{~mm} \times 320$ $\mathrm{mm} \times 25 \mathrm{~mm}$, wherein the test section length is $1000 \mathrm{~mm}$. The sides of duct are made up of $25 \mathrm{~mm}$ thick soft wood. Two batons of $25 \mathrm{~mm}$ thick soft wood to achieve the required height are placed inside the duct. Exit section is provided towards the end side of the duct followed by mixing section and should be kept as minimum value of $2.5\left(\mathrm{~A}_{\mathrm{f}}\right)^{1 / 2}$, so the length of exit section taken as $500 \mathrm{~mm}$ respectively. The purpose of mixing section is to mix the air properly so that uniform temperature of air is obtained at the outlet. Three equi-spaced baffles of aluminium sheet are arranged in $100 \mathrm{~mm}$ length after the exit section. One baffle is placed on bottom side whereas the other two are on upper side, all being of equal width as mixing section. The mixing section is joined with the M.S. pipe fitting. The exit section is connected to blower end via G. I. pipe. The length of pipe upstream of orifice plate is $1000 \mathrm{~mm}$, and downwards of orifice plate is $500 \mathrm{~mm}$, its diameter being $78 \mathrm{~mm}$. Flange taps are provided at $80 \mathrm{~mm}$ and $40 \mathrm{~mm}$ on each side of orifice plate. An orifice plate was used for the measurement of flow in the pipe as per the recommendations in [19] and is fitted in between the flanges, such that it remains concentric with the pipe. The lengths of straight pipe were suggested a minimum of $10 \mathrm{~d}_{1}$ on upstream and $5 \mathrm{~d}_{1}$ on downstream of orifice plate by [10]. Pressure taps are fitted $25.4 \mathrm{~mm}$ away on each side of orifice plate as suggested in [12]. A U-tube manometer is used for the measurement of pressure drop $(\Delta$ P) across the orifice plate. Digital manometer with least count $1 \mathrm{~mm}$ is used for the measurement of the pressure drop across the test section.

The suction end of the duct is connected to the centrifugal blower of $1.5 \mathrm{~kW}$ for forcing the air through the duct.To regulate the flow rate through the duct, gate valve is provided with pipe fittings. A digital milivoltmeter is used to indicate the thermocouple temperatures at different positions viz. duct section flow inlet and outlet, absorber plate etc. A selector switch having 12 point ports is used to measure the different point temperatures by just adjusting the selector switch. To regulate the voltage supplied to the strip heater variac is used. Thus the heat input to absorber plate can be easily varied. A voltmeter and an ammeter are used to measure down the corresponding voltage and current supplied to the strip heater. For the purpose of providing uniform heating flux to absorber plate strip heater is used, which is made up of Asbestos sheet and nichrome wires are wound on it with the help of screws. The length of the heater plate is $360 \mathrm{~mm} \times 1000 \mathrm{~mm}$. A $4 \mathrm{~mm}$ thick asbestos strip heater is provided at a distance of $25 \mathrm{~mm}$ above the absorber plate, resting on the wooden baton. For temperature measurements 28 SWG copper-constantan thermocouples are used. As per by [12] for the temperature measurements in the range from $-200^{\circ} \mathrm{C}$ to $+350^{\circ} \mathrm{C}$ copper-constantan thermocouples are best suited. Before fixing the thermocouple for temperature measurements, they are calibrated against the constant temperature water bath setup. The digital temperature display is obtained from the water bath and the thermocouple readings are obtained from the digital temperature indicator. The process is repeated in several steps of increasing temperatures of distilled water. Prior to start of experiments, all joints were properly examined and tested using soap bubble test.The entire experimental setup is assembled, with all the measuring instruments being installed in their exact positions including the electric circuit connections, variac, ammeter, voltmeter and temperature indicator components.

\section{VALIDATION OF EXPERIMENTAL SETUP}

For calibration of experimental setup, tests were conducted using the collector as smooth duct. Values of Nusselt number and friction factor were calculated for mass flow rate ranging from $0.01 \mathrm{~kg} / \mathrm{s}$ to $0.035 \mathrm{~kg} / \mathrm{s}$.

The values of experimentally obtained Nusselt number were compared with those obtained from the predicted values of 
Nusselt number based on Dittus-Boelter's correlation published in [4].

$\mathrm{Nu}_{\mathrm{s}}=0.023 \mathrm{Re}^{0.8} \operatorname{Pr}^{0.4}$

Similarly, the experimental values of friction factor have been compared with those obtained from modified Blasius's correlation given by [4].

$\mathrm{f}_{\mathrm{p}}=0.085 \operatorname{Re}^{-0.25}$

The values of Prandtl's number (Pr), thermal conductivity

(k) and dynamic viscosity $(\boldsymbol{\mu})$ have been taken in accordance with the corresponding temperatures from table of properties of air [12]. After determination of both experimental and predicted values of Nusselt number, a graph is drawn between them, as shown in Fig.2

Max deviation $=8.71 \%$

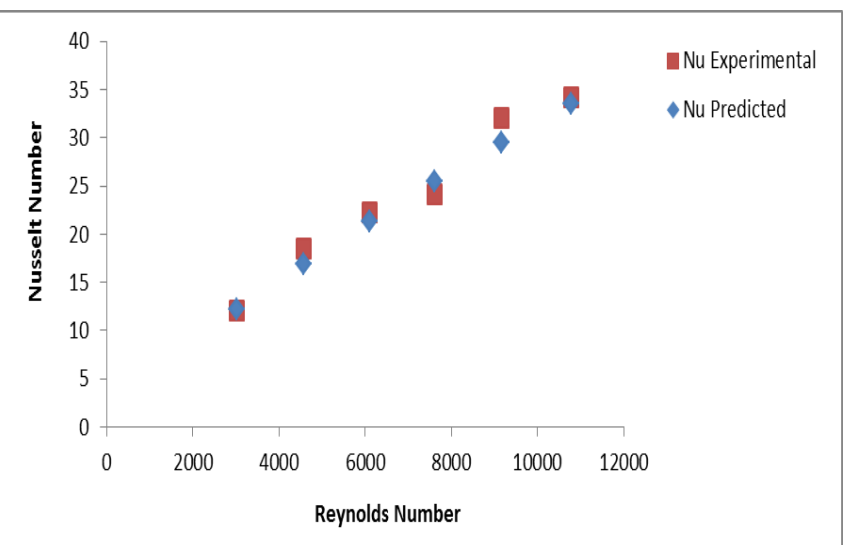

Fig.2: Experimental vs Predicted values of Nusselt's Number

Max deviation $=2.73 \%$

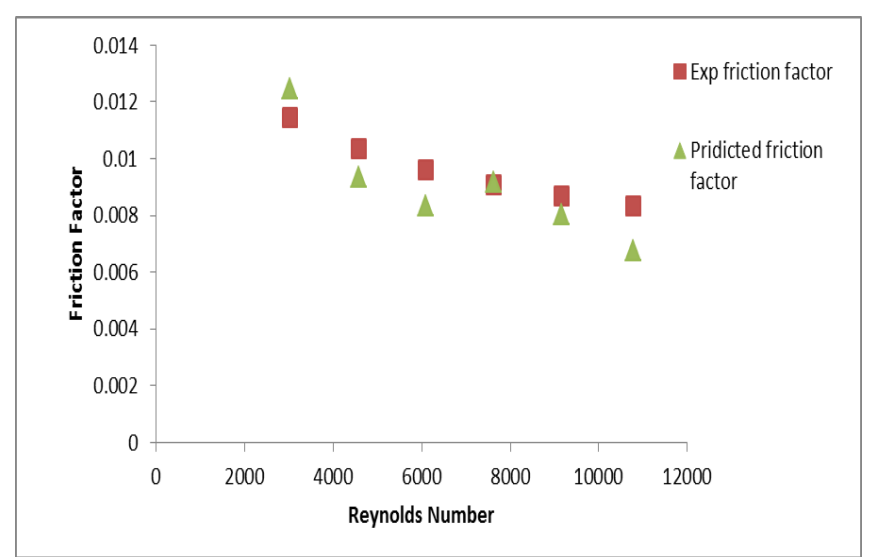

Fig.3: Experimental vs predicted values of friction factor

Comparison between experimental and predicted values of Nusselt number and friction factor has been made in Fig. 2 and Fig.3 It is seen that Nusselt number is found to have maximum deviation of $8.71 \%$ whereas the friction factor has a maximum deviation of $2.73 \%$ from the predicted values. When the calibration was found to be within satisfactory limits, the actual tests were performed on the setup to obtain data for studying the effects of various operating parameters on the performance of packed bed collectors with different types of packing elements.

\section{EXPERIMENTATION}

The collector has been tested with following packing elements for the same set of operating parameters like mass flow rate ranges from $0.01 \mathrm{~kg} / \mathrm{s}$ to $0.035 \mathrm{~kg} / \mathrm{s}$ and for the fixed depth of $25 \mathrm{~mm}$.

Table -1: Different packing materials

\begin{tabular}{|l|l|l|}
\hline $\begin{array}{l}\text { Packing } \\
\text { Materials }\end{array}$ & Diameter $(\mathbf{m m})$ & $\begin{array}{l}\text { Range Of } \\
\text { porosity }\end{array}$ \\
\hline Wire Mesh & 0.585 & $0.945-0.986$ \\
\hline Iron Chips & 0.8 & $0.945-0.986$ \\
\hline Gravels & $10-20$ & $0.4-0.45$ \\
\hline Glass balls & 10 & 0.45 \\
\hline
\end{tabular}

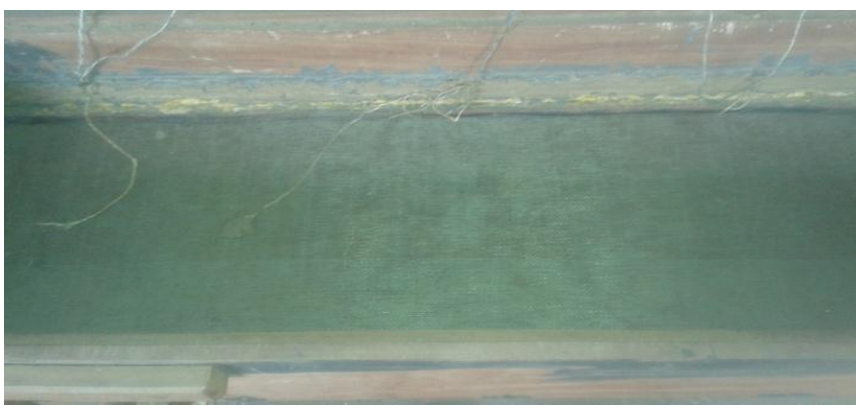

Fig.4: Duct packed with wire mesh

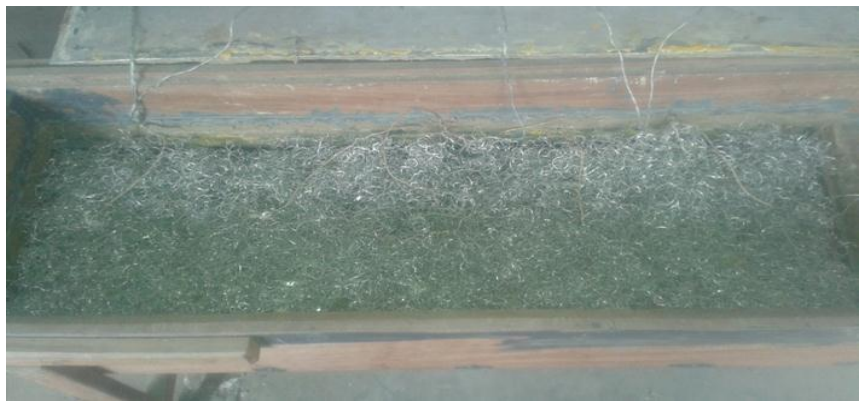

Fig.5: Duct packed with iron chips

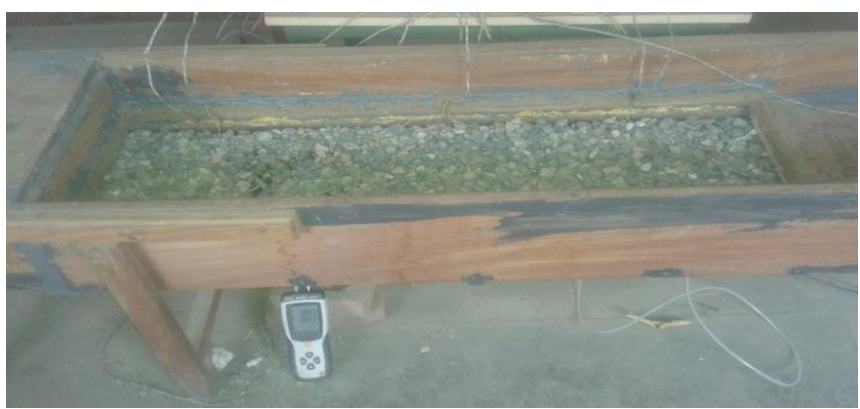

Fig.6: Duct packed with gravels 


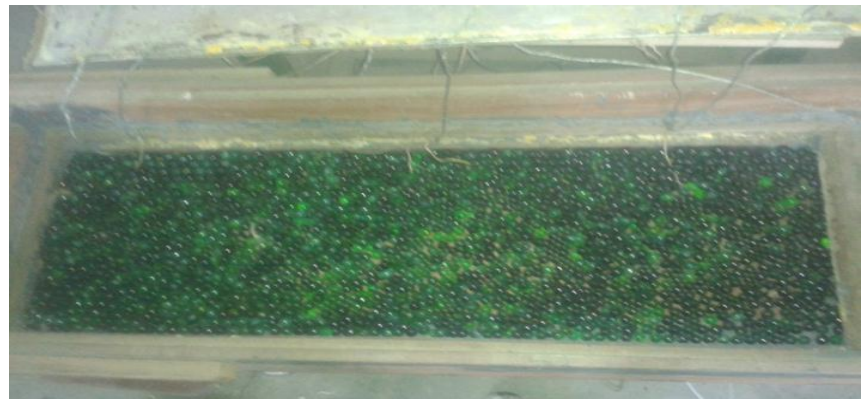

Fig.7: Duct packed with glass balls

The various parameters required to be measured for the thermal analysis of these configurations are mentioned below.

[1]. Temperature of heated absorber plate at different location equidistant apart.

[2]. Air inlet and outlet temperature.

[3]. Pressure drop across the orifice.

[4]. Pressure drop across the duct.

[5]. Insolation (simulated) per unit absorber area.

[6]. Mass flow Rate

[7]. Porosity

\subsection{Measurement of Geometrical Parameter}

An estimation of porosity can be made on the basis of void volume and total volume as under.

$P=\frac{\text { Void volume in the bed }}{\text { Total Volume of the bed }}=\frac{\mathrm{v}_{\text {woid }}}{V}$

Void volume can be estimated if the volume of the solid, $\mathrm{V}_{\mathrm{s}}$ is known.

Thus,

$$
\mathrm{V}_{\mathrm{void}}=\left(\mathrm{V}-\mathrm{V}_{\mathrm{s}}\right)
$$

$$
P=\frac{\mathrm{V}-\mathrm{V}_{\mathrm{g}}}{\mathrm{V}}
$$

For packing of irregular geometry (gravels, pebbles etc), volume of the solid in the bed matrix can be determined by volume of water displaced when the solid is immersed in it. However in case of known geometry packing's like wire mesh screen matrices, the total solid volume can be calculated based on its geometrical parameters ie. diameter of wire, pitch and number of layers.

\section{RESULT AND DISCUSSION}

As described in previous section, thermal performance of packed bed solar air heater was investigated using different packing elements to investigate the behavior of different packing elements under similar operating conditions on a single set up. This approach is adopted so as to predict an accurate and systematic comparison of performance having different packing's.

\subsection{Effect of Operating Parameters on Thermal Performance}

Discussion on effect of operating parameters has been presented in following sections.

\subsubsection{Effect of mass flow rate on thermal efficiency}

Effect of mass flow rate of air on thermal efficiency for packed bed collector packed with iron chips and wire mesh shown in Fig.8 for packing porosity of 0.945 to 0.986 respectively.

From the inspection of the figures it is observed that as the mass flow rate increases, the efficiency increases monotonously for all packing elements. This is obvious as the turbulence increases with increase in mass flow rate which increases the heat transfer between the packing and air flowing through the collector which enhances the efficiency of the collector.

From inspection of Fig. 8 it is seen that maximum efficiency of $76.21 \%$ is obtained for iron chips corresponding to porosity of 0.945 and the mass flow rate $0.035 \mathrm{~kg} / \mathrm{s}$ followed by wire mesh having a maximum efficiency of $74.26 \%$ for similar values porosity and mass flow rates. On the other hand, for the packed bed collector corresponding to porosity 0.986 and mass flow rate $0.035 \mathrm{~kg} / \mathrm{s}$, the maximum efficiency is obtained for iron chips is $48.95 \%$ followed by wire mesh matrix having a maximum efficiency of $47.88 \%$.

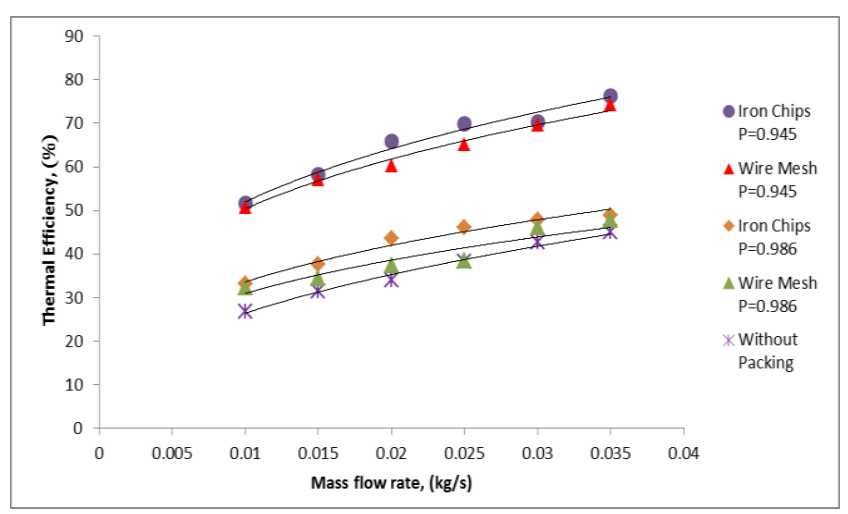

Fig. 8: Thermal efficiency vs. Mass flow rate for iron chips and wire mesh

The percentage enhancement in efficiency of iron chips packed solar collector is found to be $92.72 \%$ and $69.58 \%$ higher corresponding to smooth collector for mass flow rate $0.01 \mathrm{~kg} / \mathrm{s}$ and $0.035 \mathrm{~kg} / \mathrm{s}$ respectively followed by the wire mesh in which enhancement in efficiency found to be $89.58 \%$ and $65.24 \%$ corresponding to porosity of 0.945 and mass flow rate $0.01 \mathrm{~kg} / \mathrm{s}$ and $0.035 \mathrm{~kg} / \mathrm{s}$ respectively.

For the packed bed collector having porosity 0.986 and range of mass flow rate from $0.01 \mathrm{~kg} / \mathrm{s}$ to $0.035 \mathrm{~kg} / \mathrm{s}$ in which enhancement in efficiency is found for iron chips $23.95 \%$ and $8.7 \%$ followed by wire mesh packing in which enhancement found is $20.82 \%$ and $6.54 \%$ respectively.

It is observed that there is a significant enhancement in the value of thermal efficiency of packed bed collector having different packing elements in comparison to the 
conventional collector and among these iron chips found to be the best packing material.

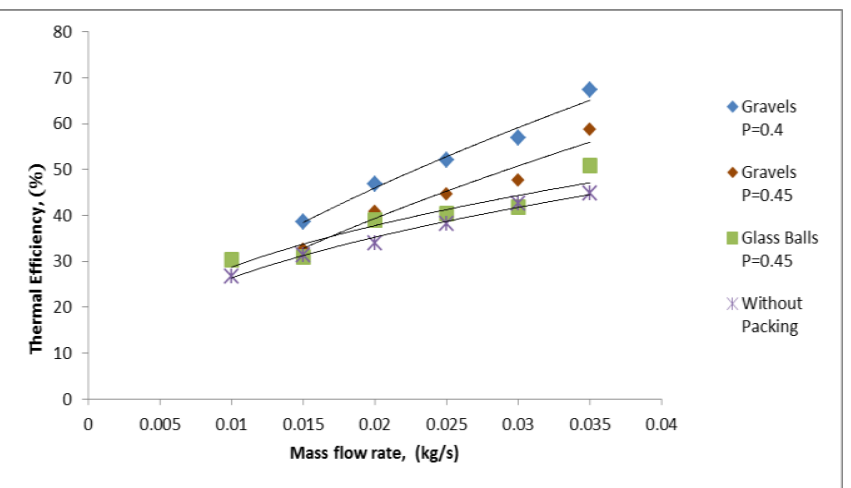

Fig.9: Thermal efficiency vs. Mass flow rate for gavels and glass balls

Comparison of performance of packed bed collector with packing's of gravel and glass balls for porosity 0.4 and 0.45 has been made in the Fig. 9. It is observed that for the gravel packed solar collector having a porosity of 0.4 , the maximum efficiency obtained is $67.42 \%$ for the mass flow rate $0.035 \mathrm{~kg} / \mathrm{s}$.

It was surprising to note that while performing the tests with mass flow rate of $0.01 \mathrm{~kg} / \mathrm{s}$ for gravels with porosity 0.4 and 0.45 , steady state could not be achieved even when the setup was run for four hours. Hence it was concluded that use of gravel for packing the solar air heater not be recommended On the other hand, glass ball packed collector corresponding to porosity of 0.45 and for mass flow rate $0.035 \mathrm{~kg} / \mathrm{s}$ to 0.01 $\mathrm{kg} / \mathrm{s}$ the efficiency found as $50.81 \%$ to $29.33 \%$ respectively.

The enhancement of efficiency in the case of glass ball packed collector has found to be $9.44 \%$ for the mass flow rate $0.01 \mathrm{~kg} / \mathrm{s}$ and for the mass flow rate of $0.035 \mathrm{~kg} / \mathrm{s}$ the enhancement in efficiency is $13.06 \%$ respectively.

\subsubsection{Effect of insolation on outlet temperature}

The effect of insolation on the outlet temperature of the collector is shown in Fig.10. It has been observed that there is no significant effect of increasing the amount of insolation.

This may be due to the fact that as we increase the value of insolation the losses are also increased in the same proportion. The net effect on the performance is thus negligible

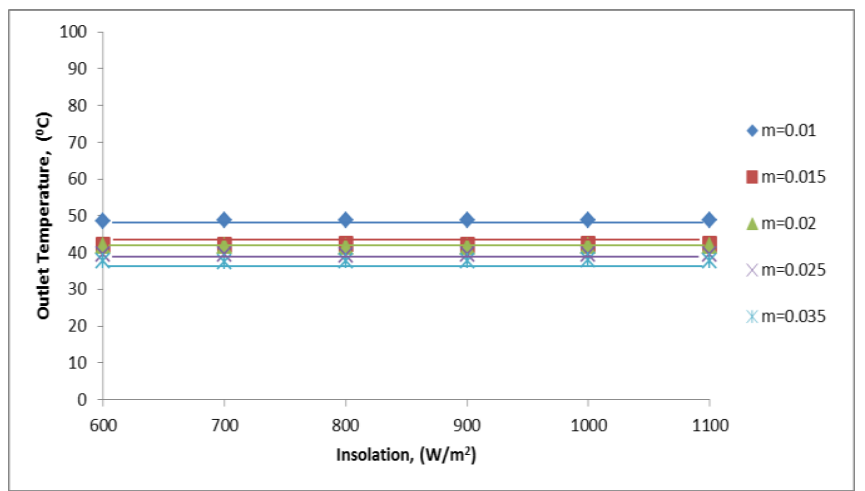

Fig.10: Effect of insolation on outlet temperature

\subsubsection{Effect of mass flow rate on effective efficiency}

In order to study the effect of mass flow rate on the effective efficiency, Fig. 11 has been drawn representing the efficiency along ordinate axis and mass flow rate on abscissa. Observation of the graph reveals that thermal efficiency keeps increasing monotonously with mass flow rate however the effective efficiency initially increases with mass flow rate and attains a maximum value and then decreases further on increasing the mass flow rate as compared to corresponding increase in heat transfer to air. This is evident from the fact that with increase in mass flow rate, pumping power increases, causing an increase in losses. Thus the useful efficiency gain starts decreasing after attaining an optimum value.

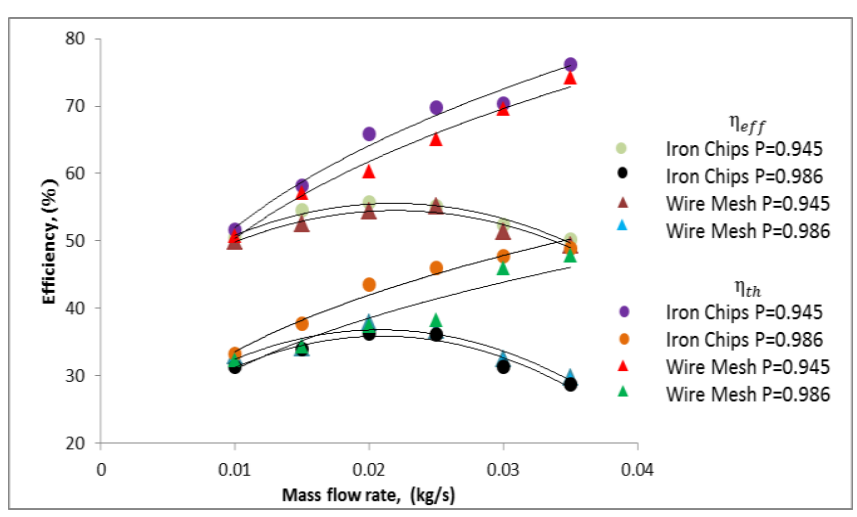

Fig.11: Effective efficiency vs. Mass flow rate for iron chips and wire mesh packed collector

Fig. 11 shows the comparison of effective efficiency and thermal efficiency with different mass flow rates for the packing of iron chips and wire mesh respectively.

Here the optimum values of effective efficiency compared to thermal efficiency corresponding to a porosity of 0.945 and mass flow rate is $0.023 \mathrm{~kg} / \mathrm{s}$ for iron chips packing is $55 \%$, followed by wire mesh having an optimum value of effective efficiency is $54 \%$.

Similarly for the porosity of 0.986 and the mass flow rate $0.023 \mathrm{~kg} / \mathrm{s}$ the effective efficiency found to be for the iron chips is $37 \%$ followed by the wire mesh having $36.1 \%$ effective efficiency .

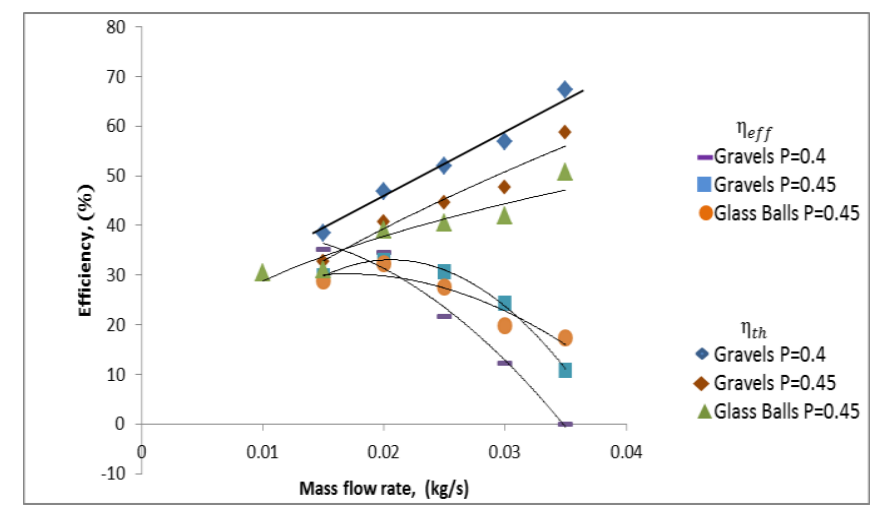

Fig.12: Effective efficiency vs. Mass flow rate for gravels and glass balls packed collector 
Comparison of effective efficiency and thermal efficiency for the gravels and glass ball packed collector for the different mass flow rates are made in Fig. 12. The optimum values of effective efficiency for the gravels packed bed collector having a porosity 0.4 is $35.1 \%$ for the mass flow rate of $0.015 \mathrm{~kg} / \mathrm{s}$ and $33 \%$ for the mass flow rate of 0.02 $\mathrm{kg} / \mathrm{s}$ corresponding to porosity of 0.45 and $32.1 \%$ for the glass ball packed bed collector having a mass flow rate of $0.02 \mathrm{~kg} / \mathrm{s}$ and porosity of 0.45 .

But gravels packed bed has very low porosity. Effective efficiency monotonously decreases with increase in flow rate as can be seen at very high air flow rate may even become negative. Therefore it is not recommended to use gravels as a packing elements for the packed bed collector.

\subsection{Heat Transfer and Pressure Drop} Characteristics

Observation of experimental results for heat transfer and pressure drop characteristics are discussed in the following sections.

\subsubsection{Heat transfer coefficient}

Fig. 13 shows the effect of mass flow rate on the heat transfer coefficient of iron chips and wire mesh packed bed collector for varraying values of porosity. It is observed that for a mass flow rate of $0.01 \mathrm{~kg} / \mathrm{s}$ and porosity of 0.945 heat transfer coefficient increases both for iron chips and wire mesh and the corresponding values are $14.11 \mathrm{~W} / \mathrm{m}^{2} . \mathrm{K}$ and $13.65 \mathrm{~W} / \mathrm{m}^{2} . \mathrm{K}$ in compared to conventional collector where value of heat transfer coefficient is found to be 7.19 $\mathrm{W} / \mathrm{m}^{2} . \mathrm{K}$.

For the porosity of 0.986 and mass flow rate $0.01 \mathrm{~kg} / \mathrm{s}$ heat transfer coefficient is found to be $9 \mathrm{~W} / \mathrm{m}^{2} \mathrm{~K}$ for the iron chips packing and $8.9 \mathrm{~W} / \mathrm{m}^{2} \mathrm{~K}$ for the wire mesh packing.

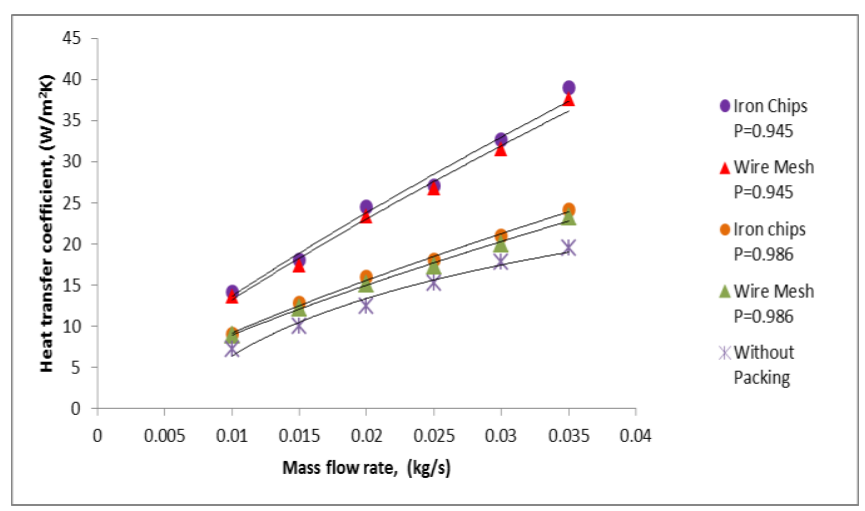

Fig.13: Heat transfer coefficient vs. Mass flow rate and porosity

The enhancement of heat transfer coefficient for the mass flow rate $0.035 \mathrm{~kg} / \mathrm{s}$ and porosity 0.945 is found to be 35.61 $\mathrm{W} / \mathrm{m}^{2} . \mathrm{K}$ for and $33.51 \mathrm{~W} / \mathrm{m}^{2} . \mathrm{K}$, for iron chips and wire mesh matrix respectively in comparison to conventional collector having heat transfer coefficient of $19.54 \mathrm{~W} / \mathrm{m}^{2} . \mathrm{K}$.

For a mass flow rare $0.035 \mathrm{~kg} / \mathrm{s}$ and porosity 0.986 the value of heat transfer coefficient is found to be $24.1 \mathrm{~W} / \mathrm{m}^{2} . \mathrm{K}$ and
$23.3 \mathrm{~W} / \mathrm{m}^{2} . \mathrm{K}$ for the iron chips packing wire mesh packing respectively.

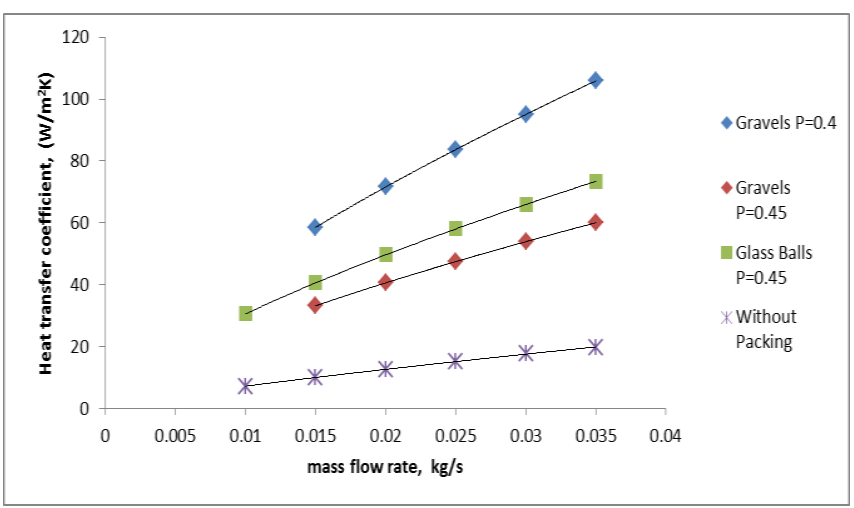

Fig.14: Heat transfer coefficient vs. Mass flow rate and porosity

Similar effect can be seen from a Fig. 14 in which gravel packed collector having a porosity 0.4 and mass flow rate $0.01 \mathrm{~kg} / \mathrm{s}$, the heat transfer coefficient is found to be 10.75 $\mathrm{W} / \mathrm{m}^{2} . \mathrm{K}$ and for the porosity 0.45 and mass flow rate 0.01 $\mathrm{kg} / \mathrm{s}$ heat transfer coefficient is $9.2 \mathrm{~W} / \mathrm{m}^{2} . \mathrm{K}$ respectively.

But as the mass flow rate increases to $0.035 \mathrm{~kg} / \mathrm{s}$ the heat transfer coefficient found to be $25.84 \mathrm{~W} / \mathrm{m}^{2}-\mathrm{K}$ for the gravel packed collector having porosity 0.4 and $23.1 \mathrm{~W} / \mathrm{m}^{2}-\mathrm{K}$ for the mass flow rate $0.035 \mathrm{~kg} / \mathrm{s}$ corresponding to a porosity of 0.45 respectively.

Similarly for the glass balls packed collector corresponding to a porosity of 0.45 , the heat transfer coefficient for a mass flow rate of $0.01 \mathrm{~kg} / \mathrm{s}$ is found to be $8.2 \mathrm{~W} / \mathrm{m}^{2} . \mathrm{K}$ and 21.1 $\mathrm{W} / \mathrm{m}^{2} . \mathrm{K}$ for the mass flow rate of $0.035 \mathrm{~kg} / \mathrm{s}$ respectively.

Heat transfer coefficient is found to increase with decrease in the value of porosity and increase in mass flow rate. This appears due to the fact that with decrease in porosity the flow passage for air becomes more tortuous giving rise to increased turbulence. Increase in mass flow rate also increases the turbulence.

\subsubsection{Pressure drop}

In a packed bed solar collector one of the most important factor taken into consideration while enhancing the heat transfer rate is the penalty of increasing the pressure drop. A digital manometer is used for the measurement of pressure across the duct for all the experimental tests runs. Pressure drop characteristics have prime importance due to its fact that this parameter is required for optimizing the system so that maximum heat transfer enhancement could be attained at the cost of minimum increase in pressure drop..

Fig. 15 is drawn to indicate the effect of pressure drop with increasing mass flow rate for an iron chips packed bed collector corresponding to a porosity of 0.945 pressure drop increases from $49.05 \mathrm{~N} / \mathrm{m}^{2}$ to $254 \mathrm{~N} / \mathrm{m}^{2}$ while for the wire mesh packed bed collector having a porosity of 0.945 pressure drop increases from $39.24 \mathrm{~N} / \mathrm{m}^{2}$ to $245.24 \mathrm{~N} / \mathrm{m}^{2}$ as the mass flow rate increases from $0.01 \mathrm{~kg} / \mathrm{s}$ to $0.035 \mathrm{~kg} / \mathrm{s}$. 


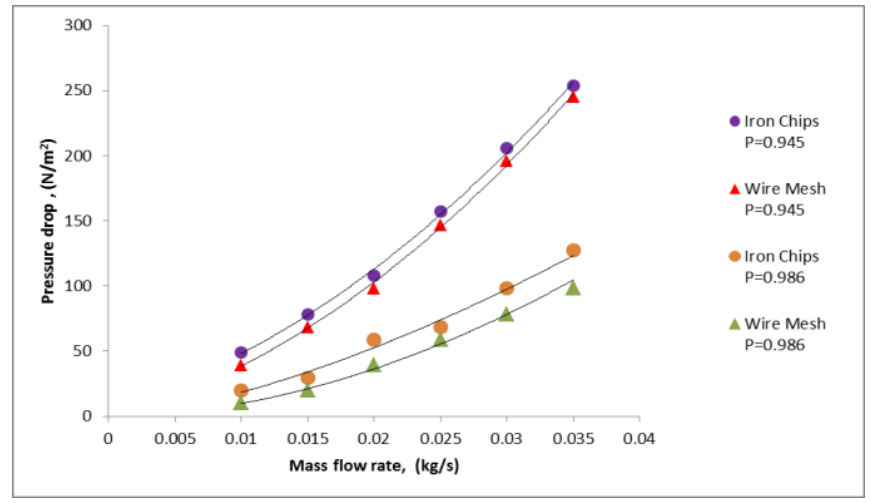

Fig.15: Pressure drop vs. Mass flow rate

Similarly for the porosity of 0.986 iron chips packed bed collector pressure drop increases from $19.62 \mathrm{~N} / \mathrm{m}^{2}$ to 127.58 $\mathrm{N} / \mathrm{m}^{2}$ while for the wire mesh packed bed collector corresponding to porosity of 0.986 pressure drop rises from $9.81 \mathrm{~N} / \mathrm{m}^{2}$ to $98.1 \mathrm{~N} / \mathrm{m}^{2}$ as the mass flow rate increases from $0.01 \mathrm{~kg} / \mathrm{s}$ to $0.035 \mathrm{~kg} / \mathrm{s}$ respectively.

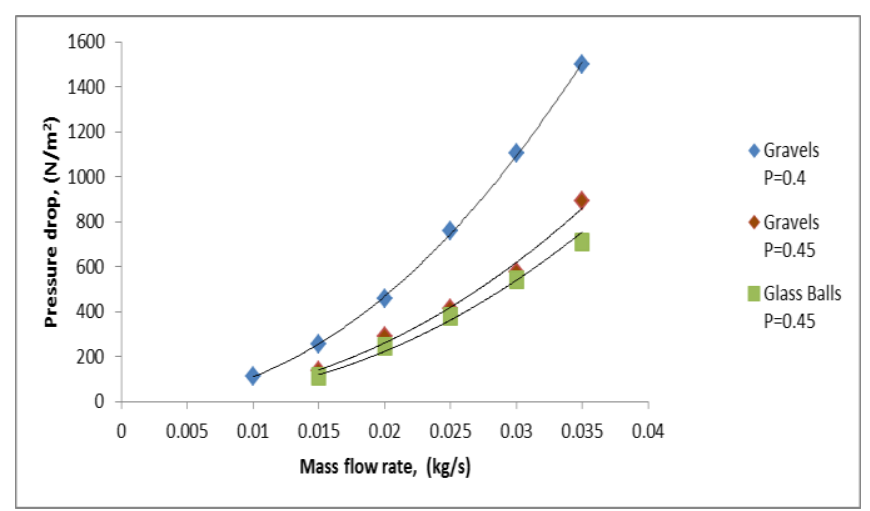

Fig.16: Pressure drop vs. Mass flow rate

Similarly from the Fig. 16 it is observed that pressure drop increases from $110 \mathrm{~N} / \mathrm{m}^{2}$ to $1498 \mathrm{~N} / \mathrm{m}^{2}$ in the case of gravel packed collector corresponding to a porosity of 0.4 while for the porosity of 0.45 pressure drop increases from $89 \mathrm{~N} / \mathrm{m}^{2}$ to $890 \mathrm{~N} / \mathrm{m}^{2}$ for the gravel packed bed collector as the mass flow rate increases from $0.01 \mathrm{~kg} / \mathrm{s}$ to $0.035 \mathrm{~kg} / \mathrm{s}$. Similarly in the case of glass balls packed collector pressure drop increases from $76.2 \mathrm{~N} / \mathrm{m}^{2}$ to $710 \mathrm{~N} / \mathrm{m}^{2}$ as the mass flow rate increases from $0.01 \mathrm{~kg} / \mathrm{s}$ to $0.035 \mathrm{~kg} / \mathrm{s}$ respectively.

From the above discussions it has been observed that as the mass flow rate increases in the case of gravels and glass balls packed bed collector there is an abruptly increase in pressure drop. This effect is attributed due to fact of low porosity in case of gravels and glass ball packed bed collector which is responsible for higher rate of increase of pressure drop.

\subsection{Comparison of the Experimental Results with}

\section{the Previous Investigators}

Comparison of the results of Colburn $\mathrm{J}_{\mathrm{h}}$ factor and the friction factor, $f_{p}$ obtained from present experimental results for wire mesh packing has been made with the results predicted by [21] and [30] in Fig. 17 and Fig. 18 .

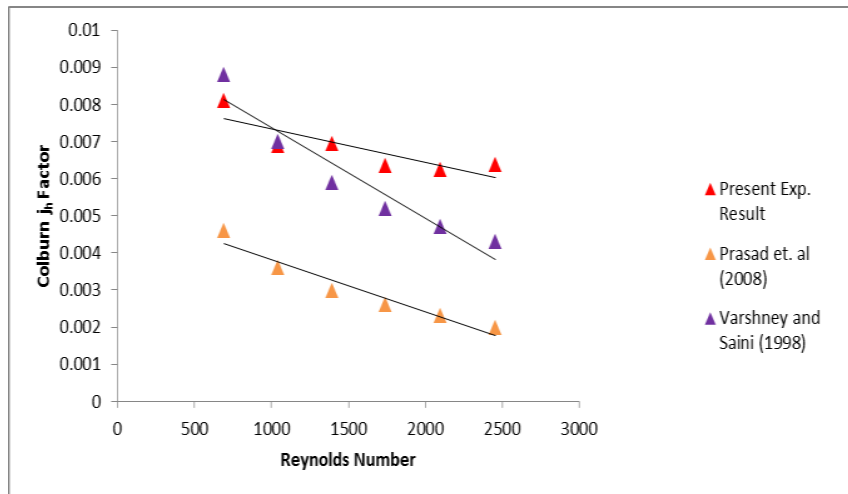

Fig.17 Comparison of the present results for colburn factor with previous investigators

From Fig. 17 it can be observed that values of Colburn $\mathbf{J}_{\mathrm{h}}$ factor have better agreement with those of the correlations developed by the previous investigators and similar behavior is observed for friction factor as shown in Fig. 18

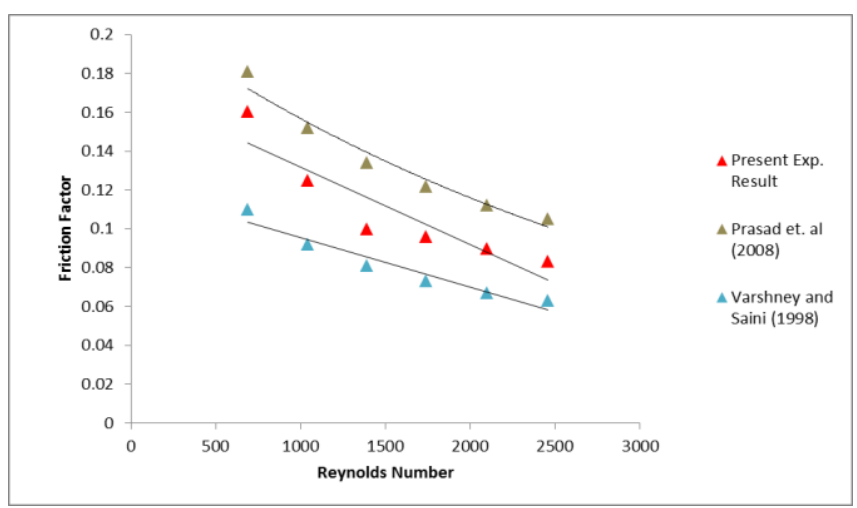

Fig.18: Comparison of the present results for friction factor with previous investigators

\subsection{Effect of Temperature Rise Parameter on the Performance of Collector}

The collectors may be designed for desired temperature rise parameter. A method for determining the design parameter for solar air collector of known dimensions and characteristics, for different operating conditions is based on the recommendations in [24]. Fig. 19 and Fig. 20 shows the plots of thermal efficiency of packed bed collector vs temperature rise parameter (To-Ti)/I for different values of mass flow rates and are compared with the corresponding performance of conventional collector.

It can be noticed that collector thermal efficiency decreases with increase in the temperature rise parameter. This is an expected behavior owing to the fact that for a given value of incident solar radiation and inlet air temperature, the outlet temperature of air decreases as the mass flow rate increases, thereby efficiency increases as temperature rise parameter decreases and vice-versa. 


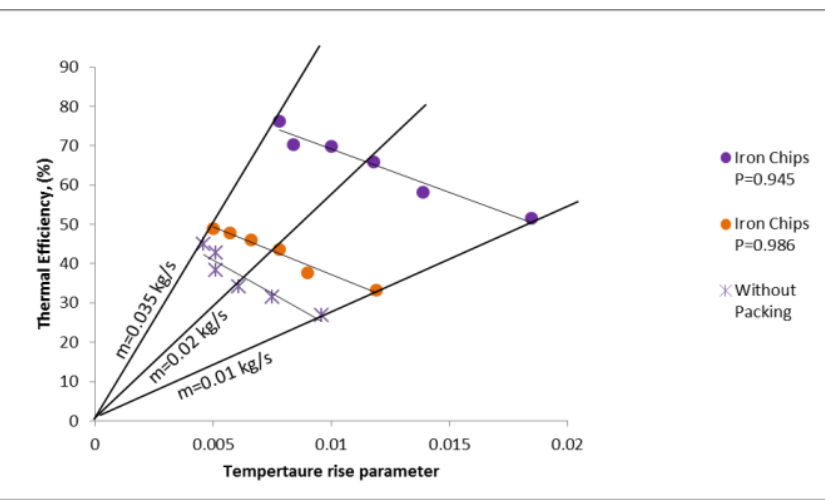

Fig.19: Thermal efficiency vs. Temperature rise parameter for iron chips packed collector

A plot of thermal efficiency against temperature rise parameter helps in determining the mass flow rate for a given temperature rise parameter, when inlet and out let temperatures are known. . Hence the efficiency required for that particular application can be directly obtained by the use of these graphs.

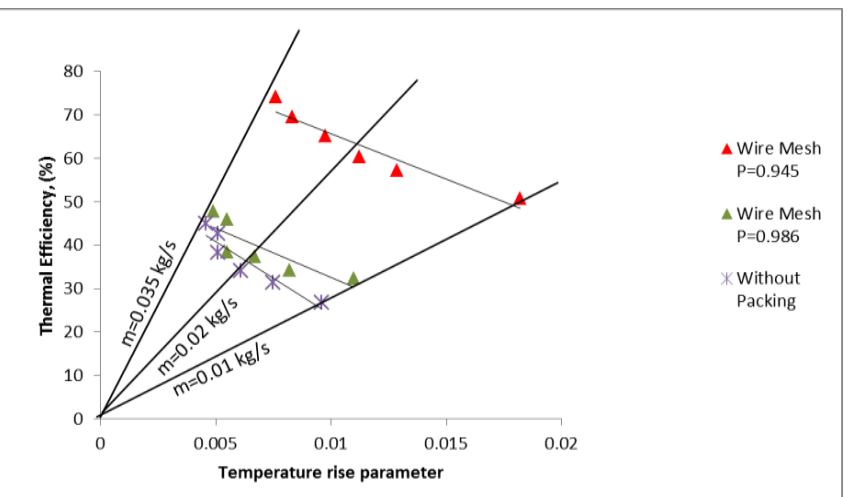

Fig.20: Thermal efficiency vs. Temperature rise parameter for wire mesh packed bed collector

For example if the given insolation is $1000 \mathrm{~W} / \mathrm{m}^{2} \mathrm{~T}_{\mathrm{o}}=47^{\circ} \mathrm{C}$ and $\mathrm{T}_{\mathrm{i}}=28{ }^{\circ} \mathrm{C}$ then one can easily obtain the temperature rise parameter i.e. $\left(\mathrm{T}_{\mathrm{o}}-\mathrm{T}_{\mathrm{i}} / \mathrm{I}\right)$ which comes out to be 0.019 . Then moving vertically upwards from 0.019 in Fig. 19 to meet the performance curve at a point, corresponding to which mass flow rate is $0.01 \mathrm{~kg} / \mathrm{s}$ and corresponding efficiency is found to be $53 \%$.

\section{CONCLUSIONS}

Based on the experimental investigations conducted under similar operating conditions on the same experimental setup, the following conclusions are drawn.

[1]. Thermal performance of packed bed collector is found to be higher as compared to conventional collector. It is observed that efficiency of iron chips packed collector with porosity of 0.945 is found to be $51.65 \%$ and $76.24 \%$ for corresponding values of mass flow rate of $0.01 \mathrm{~kg} / \mathrm{s}$ and $0.035 \mathrm{~kg} / \mathrm{s}$ respectively. This indicates an enhancement in efficiency of $92.72 \%$ to $69.58 \%$ as compared to conventional collector for the mass flow rate varying from $0.01 \mathrm{~kg} / \mathrm{s}$ to $0.035 \mathrm{~kg} / \mathrm{s}$. A similar effect is observed for wire mesh packed collector. The efficiency with porosity of 0.945 is found to be $50.81 \%$ and $74.21 \%$ for corresponding mass flow rates of 0.01 $\mathrm{kg} / \mathrm{s}$ and $0.035 \mathrm{~kg} / \mathrm{s}$. Thus the efficiency enhancement for the wire mesh packed collector increases by $89.58 \%$ to $65.28 \%$ in comparison to smooth collector for the mass flow rate varying from $0.01 \mathrm{~kg} / \mathrm{s}$ to 0.035 $\mathrm{kg} / \mathrm{s}$ respectively.

[2]. It is observed that steady state conditions cannot be achieved when collector is operated with gravels as packing elements at low mass flow rate in the range of $0.01 \mathrm{~kg} / \mathrm{s}$.

[3]. Efficiency of packed bed collector packed with gravels is found to increase by $67.42 \%$ compared to smooth collector when operated with mass flow rate of 0.035 $\mathrm{kg} / \mathrm{s}$ and porosity 0.04 .The enhancement in efficiency becomes $50.02 \%$ when porosity is 0.04 and mass flow rate of $0.035 \mathrm{~kg} / \mathrm{s}$. Similarly corresponding to a porosity of 0.45 , the efficiency found for the glass balls packed collector is $29.33 \%$ and $50.81 \%$ for the mass flow rate of $0.01 \mathrm{~kg} / \mathrm{s}$ and $0.035 \mathrm{~kg} / \mathrm{s}$ respectively. The enhancement in efficiency is observed for the glass ball packed collector $9.44 \%$ and $13.06 \%$ for the mass flow rate of $0.01 \mathrm{~kg} / \mathrm{s}$ and $0.035 \mathrm{~kg} / \mathrm{s}$ respectively.

[4]. The thermal efficiency keeps on increasing with the increase in mass flow rate where as effective efficiency increases with increase in mass flow rate, attains a maxima and subsequently decreases with the increase in mass flow rate, because the rate of increase in pressure loss is much higher in comparison to the rate of increase in heat transfer from packing to air. The optimum a value of effective efficiency corresponding to a porosity of 0.945 for iron chips packing is found to be $55 \%$ followed by wire mesh having an effective efficiency of $54 \%$ at the mass flow rate of $0.023 \mathrm{~kg} / \mathrm{s}$. The effective efficiency for the gravels packed collector is $35.1 \%$ corresponding to a porosity 0.4 at the mass flow rate of $0.015 \mathrm{~kg} / \mathrm{s}$ and $32.1 \%$ for the glass ball packed bed collector having a porosity of 0.45 at the mass flow rate of $0.02 \mathrm{~kg} / \mathrm{s}$. This effect is evident from the fact that with increase in mass flow rate, pumping power increases causes an increase in losses. Thus the useful efficiency gain starts decreasing after attaining an optimum value. But gravels packed bed has very low porosity. Effective efficiency monotonously decreases with increase in flow rate as can be seen at very high air flow rate may even become negative. Therefore it is not recommended to use gravels as a packing elements for the packed bed collector.

[5]. The net effect of insolation on the thermal performance is found to be negligible due to the fact that with increase in insolation the losses are also increased in the same proportion.

[6]. Geometry of the packing is found to affect the performance of the collector. It is seen that collector performs with lower porosity packing's in all packing materials.

[7]. It is seen that the heat transfer coefficient increases with increase in mass flow rate and with decrease in porosity. Iron chips packed collector with porosity 
0.945 shows better heat transfer characteristics as compared to porosity of 0.986 . Similar effect is found in the case of wire mesh packed collector for the same set of porosity range. This effect is also seen in the case of gravels and glass balls packed bed collector corresponding to a porosity of 0.4 and 0.45 .

[8]. Study of pressure drop characteristics indicate that while enhancing the heat transfer coefficient of packed bed collector packed with different packing elements there is a penalty of increase in pressure drop across the duct. Pressure drop with iron chips is higher as compared to wire screen in the entire range of mass flow rate. Pressure drop with iron chips is $49.05 \mathrm{~N} / \mathrm{m}^{2}$ and $254 \mathrm{~N} / \mathrm{m}^{2}$ with mass flow rate of $0.01 \mathrm{~kg} / \mathrm{s}$ and $0.035 \mathrm{~kg} / \mathrm{s}$ as compared to wire mesh which is 39.24 $\mathrm{N} / \mathrm{m}^{2}$ and $245 \mathrm{~N} / \mathrm{m}^{2}$. In the case of gravels and glass balls packed bed collector where a very low porosity range is found, so the pressure drop is much higher as compared to iron chips and wire mesh packing.

[9]. Comparisons of experimental results of Colburn $J_{h}$ factor and the friction factor with the correlation developed by the previous investigators are found to be in good agreement.

\section{REFERENCES}

[1]. Ahmad, A., Saini, J.S. and Varma, H.K. 1995. Effect of geometrical and thermophysical characteristics of bed materials on the enhancement of thermal performance of packed bed solar air heaters. Energy Convers. Management. 36 (12): 1185-1195.

[2]. Ahmad, A., Saini, J.S. and Varma, H.K. 1996. Thermohydraulic performance of packed bed solar air heater. Energy Convers. Management. 37 (2): 205214.

[3]. ASHRAE Standard. 1977. Methods of Testing to Determine the Thermal Performance of Solar Collectors. ASHRAE, New York. pp. 93-97.

[4]. Bhatti, M.S. and Shah, R.K., 1987. Turbulent and transition convective heat transfer in ducts, Handbook of Single phase convective Heat Transfer edited by Kakac, S., Shah, R.K. and Aung W. Wiley, New York.

[5]. Chiou, J.P., El-Wakil, M.M. and Duffle, J.A. 1965. A slit and expanded aluminium foil matrix solar collector. Solar Energy. 9: 73-80.

[6]. Choudhury, C. and Garg, H. P. 1993."Performance of Air-Heating Collectors with Packed Air Flow Passage", Solar Energy. 50 (3): 205-221.

[7]. Choudhury, C., Garg, H.P. and Prakash, J. 1993. Design studies of packed-bed solar air heaters. Energy Conversion Management. 34 (2): 125-138.

[8]. [8]. Demirel, Y. and Kunc, S. 1987. Thermal performance study of a solar air heater withpacked flow passage, Energy Convers. Management. 27 (3): 317-325.

[9]. Dhiman, P., Thakur, N.S., Kumar, A. and Singh, S. 2011. An analytical model to predict the thermal performance of a novel parallel flow packed bed solar air heater. Appl. Energy. 88: 2157-2167.
[10]. Ehlinger, A.H.,1950, Flow of air and gases, Kent's mechanical Engineers Handbook, Power Vol., 1.101.2, Johnwiley, New York.

[11]. Hamid, Y.H. and Beckman, W.A. 1971. Performance of air-cooled radiatively heated screen matrices. $J$. Eng. Power. 93: 221-224.

[12]. Holman, J.P. and Gajda, W.J. Jr.,1984. Experimental Methods for Engineers, IV Ed., McGraw-Hill Book Co. Singapore.

[13]. Kapardar, A.K. and Sharma, R.P., 2012. Experimental Investigation Of Solar Air Heater Using Porous Medium. International Journal of Mechanical Engineering amd Technology ( IJMET) Volume 3, Issue 2, pp. 387-396.

[14]. Kays, W.M. and London, A.L. 1964. Compact Heat Exchangers. McGraw-Hill, New York.

[15]. Mittal, M.K. and Varshney, L. 2006. Optimal thermohydraulic performance of a wire mesh packed bed solar air heater. Solar Energy. 80: 1112-1120.

[16]. Mishra, C.B. and Sharma, S.P. 1981. Performance study of air-heated packed bed solar energy collector, Int. J. Energy. 6: 153-157.

[17]. Ozturk, H.H. and Demirel, Y. 2004. Exergy-based performance analysis of packed bed solar air heaters. Int. J. Energy Res. 28: 423-432.

[18]. Omojaro, A.P.and Aldabbagh, L.B.Y. 2010. Experimental performance of single and double pass solar air heater with fins and steel wire mesh as absorber. Applied Energy. 87: 3759-3765.

[19]. Preobrazhensky, V.P.,1980. Measurement and instrumentation in heat engineering, Vol. II(English Translation), Mir Publishers, Moscow.

[20]. Prasad, R.K. and Saini, J.S. 1993. Comparative performance study of packed bed solar air heaters, Emerging trends in Mech. Engg., Proc. Of $8^{\text {th }}$ ISME Conference on Mech. Engg., I.I.T., Delhi.

[21]. Prasad, S.B., Saini, J.S. and Singh, K.M. 2008. Investigation of heat transfer and friction characteristics of packed bed solar air heater using wire mesh as packing material. Solar Energy. 83: 773-783.

[22]. Paul, B. and Saini, J.S. 2003. Thermohydraulic performance of pebble bed solar air heaters, International Conference on Mechanical Engineering 2003 (ICME2003) 26- 28 December 2003, Dhaka Bangladesh.

[23]. Ramadan, M.R.I., El-Sebaii, A.A., Aboul-Enein, S. and El-Bialy, E. 2007. Thermal performance of a packed bed double-pass solar air heater. Energy 32: 1524-1535.

[24]. Reedy, T.A. and Gupta C.L. 1980.Generating application design data for solar air heating systems. Solar Energy. Vol.25, pp.527-530.

[25]. Singh, P. 1978. Cheap packed bed absorbers for solar air heaters, Proc. Int. Solar Energy Society Cong., Vol. II, New Delhi, 900-904.

[26]. Singh, R., Saini, R.P. and Saini, J.S. 2006. Nusselt number and friction factor correlations for packed bed solar energy storage system having large sized elements of different shapes. Solar Energy. 80: 760771 . 
[27]. Sodha, M.S., Bansal, N.K., Singh, D. and Bharadwaj, S.S. 1982. Performance of a matrix air heater, $J$. Energy, 6 (5), 334-339.

[28]. Sukhatme, S.P. 1987. Solar Energy: Principles of thermal collection and storage. New Delhi, India, Tata McGraw-Hill.

[29]. Thakur, N.S., Saini, J.S. and Solanki, S.C. 2003. Heat transfer and friction factor correlations for packed bed solar air heater for a low porosity system. Solar Energy. 74: 319-329.

[30]. Tian, J., Kim, T., Lu, T.J., Hodson, H.P., Queheillalt, D.T., Sypeck, D.J, Wadley and H.N.G., 2004. The effects of topology upon fluid flow and heat transfer within cellular copper structures. Int. J. Heat Mass Transfer. 47: 3171-3186.

[31]. Varshney, L. and Saini, J.S. 1998. Heat transfer and friction factor correlations for rectangular solar air heater duct packed with wire mesh screen matrices. Solar Energy. 62 (4): 255-262.

[32]. Varshney, L. 1999. Investigation of thermo hydraulic performance of packed bed solar air heaters. Thesis, Ph.D. University of Roorkee, Roorkee. 200-207. 